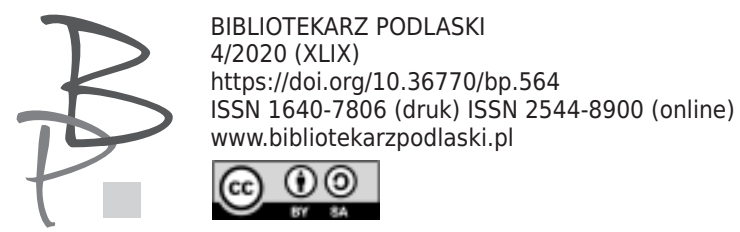

Krzysztof Rutkowski*

Uniwersytet w Białymstoku

https://orcid.org/0000-0002-2474-3621

\title{
Międzynarodowa Konferencja Naukowa „Monastycyzm i mistycyzm w literaturze, kulturze i języku Słowian", Białystok - Supraśl, 28-29 września 2020 roku (VI edycja cyklu). Sprawozdanie
}

International Scientific Conference "Monasticism and Mysticism in the literature, culture and language of the Slavs", Białystok - Supraśl, September 28-29, 2020 (6th edition of the cycle). A report

Cyk1 międzynarodowych konferencji naukowych „Chrześcijańskie dziedzictwo duchowe narodów słowiańskich. Język. Literatura. Kultura. Historia" zapoczątkowała w 1998 roku prof. Zofia Abramowicz, znakomita znawczyni onomastyki pogranicza polsko-litewsko-białoruskiego ${ }^{1}$. Za swe

Krzysztof Rutkowski - dr, pracuje na Wydziale Filologicznym Uniwersytetu w Białymstoku. Autor monografii Leksyka konfesyjna w języku rosyjskim okresu radzieckiego (Białystok 2008) oraz prac poświęconych zagadnieniom polsko-rosyjskiej homonimii międzyjęzykowej w ujęciu diachronicznym.

1 Zob. Z. Abramowicz, Imiona chrzestne białostoczan w aspekcie socjolingwistycznym (lata 1885-1985), Białystok 1993; Antroponimia Żydów białostockich, Białystok 2010; Stownik etymologiczny nazwisk Żydów białostockich. Białystok 2003; Nazwy własne na pograniczach etnicznojęzykowych, red. Z. Abramowicz, L. Dacewicz, Białystok 1999; Onimizacja i apelatywizacja, red. Z. Abramowicz, E. Bogdanowicz, Białystok 2006. 


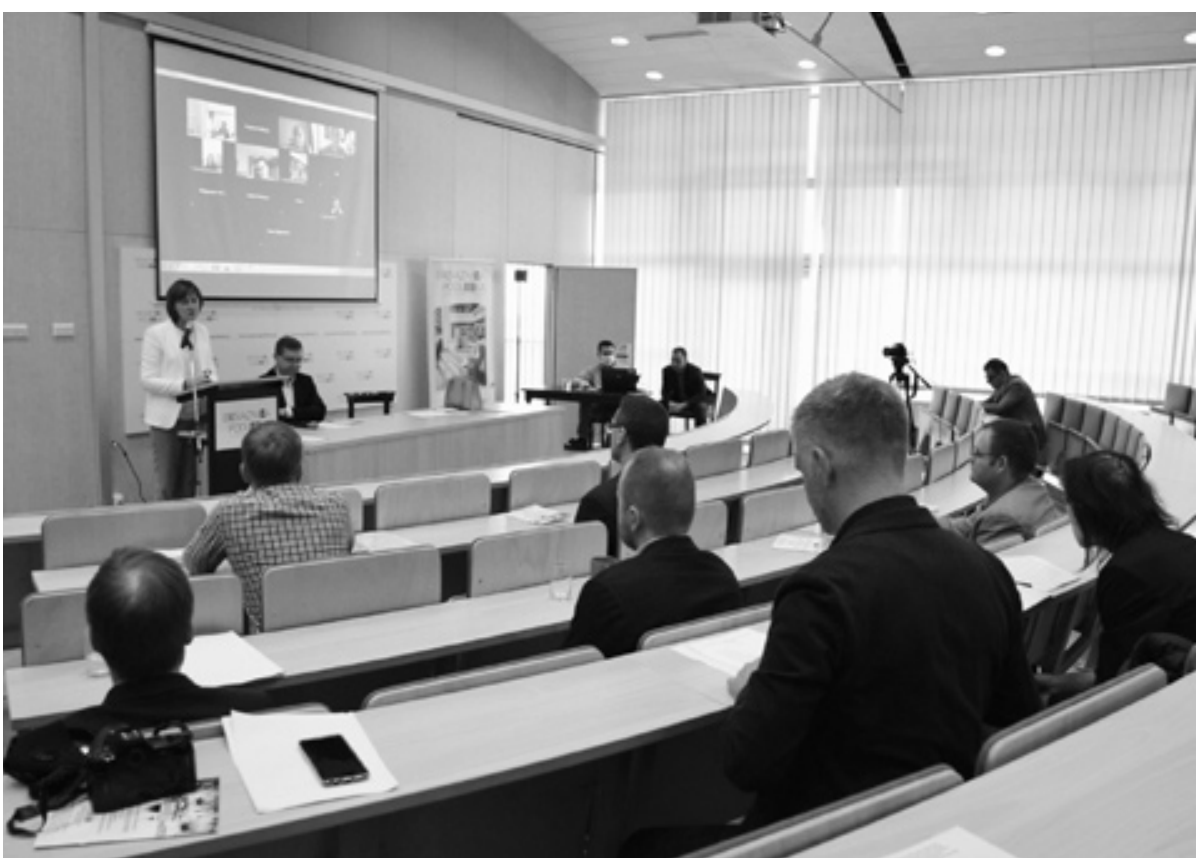

Sala obrad. Otwarcie Konferencji.

Przemawia prof. dr hab. Lilia Citko (UwB, Białystok)

zasługi dla białostockiego środowiska językoznawczego została ona uhonorowana w 2019 roku okazałym Jubileuszem i Księgą ${ }^{2}$. Pani prof. Abramowicz patronowała osobiście V edycjom interdyscyplinarnych spotkań w Białymstoku, Białowieży i Supraślu, połączonych zazwyczaj z odbywającymi się w tym samym czasie festiwalami muzyki cerkiewnej. Były to sesje poświęcone zawsze - tak dziś passé, niemodnemu - tematowi chrześcijańskich korzeni, wspólnych źródeł narodów słowiańskich, jakże często eksponujących wytworzone w procesie historycznym różnice między sobą ${ }^{3}$. Już za to należały się Pani Profesor słowa wdzięczności, których też Jej nie szczędzono,

2 Nazwy wlasne w języku, literaturze i kulturze. Ksiega Jubileuszowa dedykowana Profesor Zofii Abramowicz, red. A. Rygorowicz-Kuźma, K. Rutkowski, Białystok 2019, ss. 696.

3 Por. J. Ławski, Pani Profesor Zofia Abramowicz - osobowość białostockiego środowiska językoznawczego; L. Dacewicz, Pani Profesor Zofia Abramowicz - kilka uwag o pracy badawczej i podróżach naukowych; B. Walczak, Profesor Zofia Abramowicz na tle polskiego językoznawstwa, [w:] Nazwy wtasne..., dz. cyt., s. 21-38. 
gdy przed rokiem odchodziła na emeryturę, żegnając się z uczelnią kolejną monografią... ${ }^{4}$

Owocem sesji są w sumie IV zbiory publikacji (w tym dwa dwutomowe), wydanych w latach 2003-20195. Ideę prof. Abramowicz środowisko jej współpracowników, do których mamy zaszczyt należeć, postanowiło kontynuować - na rok 2020 zaplanowano VI Konferencję, poświęconą tym razem „Monastycyzmowi i mistycyzmowi w literaturze, kulturze i języku Słowian”. Początkowo sesję zaplanowano w maju 2020 roku w Supraślu, ale wybuch pandemii, lockdown, lęki przez koronawirusem, a nade wszystko zdrowy rozsądek, kazały imprezę przenieść na jesień tegoż roku. Dziś, gdy to piszemy (30 września 2020 roku), wiemy, iż pandemia w ten czy inny sposób będzie nam towarzyszyć do końca 2021 roku, a jesienią tego roku również w Polsce przyjdzie i do nas tzw. druga fala pandemii. Sesję postanowiliśmy jednak, by zachować świętą tradycję, odbyć w formule dostosowanej do czasów, w których przyszło nam żyć. Co znamienne, jej uczestnicy już do lipca br. nadesłali niemal wszystkie prace przeznaczone do wygłoszenia, tak, iż w 2021 roku z pewnością ukaże się kolejna monografia zbiorowa z tej serii.

Przywołajmy najpierw kluczowe informacje o wydarzeniu. Jego organizatorami byli: Wydział Filologiczny Uniwersytetu w Białymstoku, Katedra Badań Filologicznych „Wschód - Zachód”, Zakład Historycznego Językoznawstwa Słowiańskiego, Pracownia Komparatystyki Kulturowej, Książnica Podlaska im. Łukasza Górnickiego w Białymstoku oraz Akademia Supraska i Stowarzyszenie Naukowe „Oikoumene”.

4 Z. Abramowicz, Imiona biblijne w historycznej antroponimii Podlasia (XVI-XVII w.), Białystok 2020.

5 Są to następujące publikacje: Chrześsijańskie dziedzictwo duchowe narodów słowiańskich, red. Z. Abramowicz, Wydawnictwo UwB, Białystok 2003, ss. 667; Chrześcijańskie dziedzictwo duchowe narodów stowiańskich, seria 2: Wokół kultur śródziemnomorskich, t. 1, Literatura i stowa, red. Z. Abramowicz i J. Ławski, Trans Humana, Białystok 2009, ss. 694; Chrześcijańskie dziedzictwo duchowe narodów stowiańskich, seria 2: Wokót kultur śródziemnomorskich, t. 2, Historia, język, kultura, red. Z. Abramowicz i J. Ławski, Trans Humana, Białystok 2010, ss. 563; Chrześcijańskie dziedzictwo duchowe narodów stowiańskich, seria 3, t. 1, Chrześcijaństwo w literaturze i języku, red. A. Zbramowicz i K. Korotkich, Wydawnictwo Prymat, Białystok 2016, ss. 453; Chrześcijańskie dziedzictwo duchowe narodów stowiańskich, seria 3, t. 2, Chrześcijaństwo w literaturze i języku, red. Z. Abramowicz i K. Korotkich, Wydawnictwo Prymat, Białystok 2016, ss. 402; Chrześcijańskie dziedzictwo duchowe narodów stowiańskich, seria 4, Kultury słowiańskie wobec dziedzictwa Oświecenia, red. Z. Abramowicz, J. Ławski, K. Rutkowski, Białystok 2019. 
Spotkanie organizowali wraz z Komitetem Organizacyjnym ${ }^{6}$ i pod okiem Komitetu Naukowego ${ }^{7}$ działającego od lat: prof. Jarosław Ławski, dr hab. Lilia Citko, prof. UwB, dr hab. Krzysztof Korotkich i dr Krzysztof Rutkowski. Komitetowi Naukowemu przewodniczyła honorowo prof. Zofia Abramowicz, zaś Komitet Organizacyjny mieścił się w Katedrze Badań Filologicznych „Wschód - Zachód”. Podczas sesji rozpatrywano następujące zagadnienia:

- Klasztory słowiańskie Zachodu i Wschodu i ich wpływ na życie państw, narodów, na rozwój nauki i kultury.

- Życie naukowe w klasztorach.

- Literacki obraz mnicha i klasztoru.

-Wzajemne relacje i wpływy klasztorów wschodnich i zachodnich.

- Klasztory jako centra wydarzeń historycznych, politycznych oraz społecznych.

- Słowianie wobec chrześcijańskiego dziedzictwa językowego, historycznego, literackiego i kulturowego.

- Utrwalone w piśmiennictwie języków słowiańskich świadectwa życia monastycznego.

- Biblia i jej recepcja w świecie słowiańskim, symbolika biblijna oraz jej implikacje w języku, literaturze i kulturze.

- Duchowość i mistyka w pismach Ojców Kościoła - aspekty filologiczne.

Z powodów oczywistych - bezpieczeństwa - obrady przeniesiono z Supraśla i sal Uniwersytetu w Białymstoku do Sali Audytoryjnej Książnicy Pod-

6 W skład Komitetu Organizacyjnego weszli: prof. dr hab. Jarosław Ławski KBF „Wschód - Zachód" - Przewodniczący, dr hab. Lilia Citko, prof. UwB - ZHJS KJ - Przewodniczaca, dyr. Jolanta Gadek - Książnica Podlaska, dr Krzysztof Rutkowski - ZHJS KJ - Sekretarz, mgr Patryk Suchodolski - Książnica Podlaska, dr hab. Krzysztof Korotkich - KBF „Wschód - Zachód” Sekretarz, dr Małgorzata Kurianowicz - ZHJS KJ, dr Anna Rygorowicz-Kuźma - ZHJS KJ, mgr Joanna Godlewska - KBF „Wschód - Zachód”.

7 Komitet Naukowy cyklu konferencyjnego od kilku lat tworzą: prof. Zofia Abramowicz Przewodniczaca, prof. Andrzej Baranow (Wilno), prof. Wojciech Chlebda (Opole), prof. Leonarda Dacewicz (Białystok), prof. Anna Miezienko (Witebsk), prof. Jarosław Poliszczuk (Poznań), prof. Wanda Supa (Białystok), prof. Elżbieta Wesołowska (Poznań), dr hab. Urszula Cierniak, prof. AJD (Częstochowa), dr hab. Anna Janicka, prof. UwB (Białystok), ks. dr hab. Marek Ławreszuk (Białystok), dr hab. Marek Nalepa, prof. UR (Rzeszów), ks. prof. Jacek Pawlik (Olsztyn), dr hab. Anna Wydrycka, prof. UwB (Białystok), dr hab. Corinne Fournier Kiss (Berno), dr hab. Edward Jakiel, prof. UG (Gdańsk), dr hab. Swietłana Suchariewa (Łuck), dr Jolanta Doschek (Wiedeń), ks. dr Tadeusz Kasabuła (Białystok), dr Łukasz Zabielski (Białystok). 


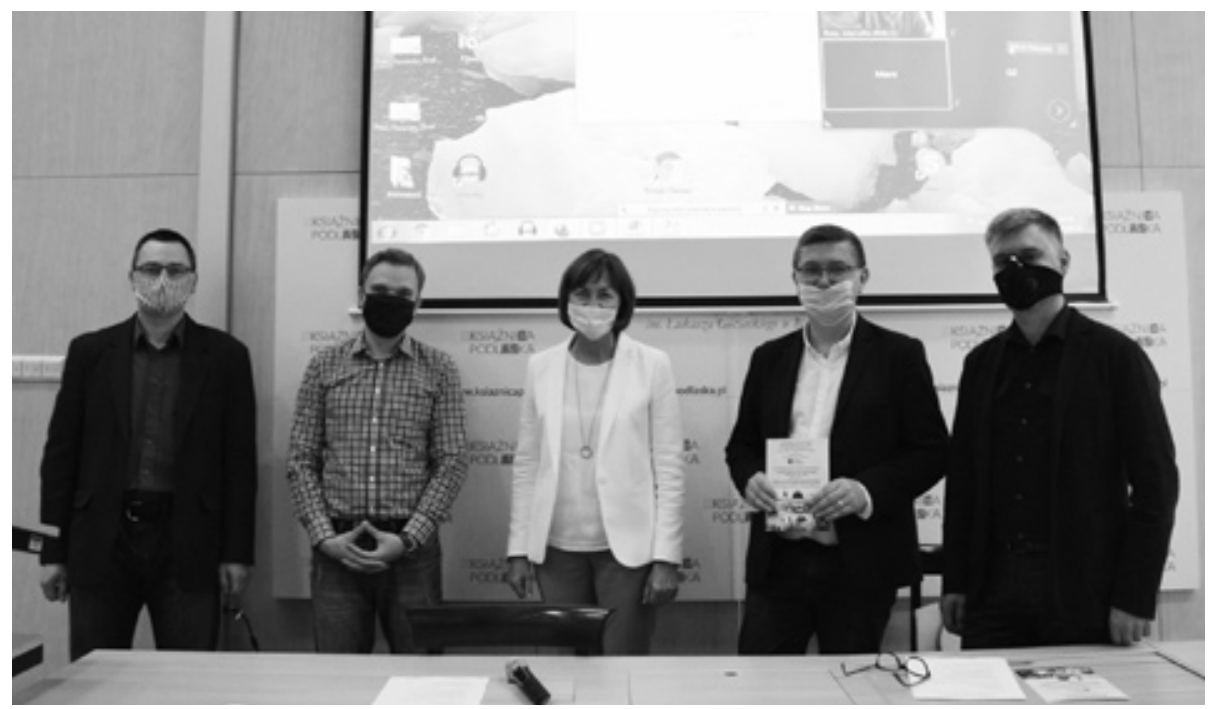

Na zdjęciu stoją od lewej: dr Krzysztof Rutkowski, dr Łukasz Zabielski, prof. Lilia Citko, prof. Jarosław Ławski, dr hab. Krzysztof Korotkich

laskiej im. Łukasza Górnickiego. Zmieniono również pierwotny układ sesji: dzień pierwszy poświęcono na obrady, prowadzone w formule mieszanej: część uczestników wystąpiła na żywo, część online. Dzień drugi umożliwił indywidualne (wobec niemożliwości grupowego wyjazdu) wizyty w Supraślu i na Podlasiu takich uczestników Konferencji, jak prof. Włodzimierz Szturc (UJ, Kraków), od lat współpracujący z białostockim środowiskiem slawistycznym $^{8}$. Ograniczono, niestety, liczbę słuchaczy obrad stacjonarnych, wychodząc z założenia, iż bezpieczeństwo jest absolutnym priorytetem uczestników i organizatorów.

Spotkanie 28 września (poniedziałek) o godz. 9.30 otworzyli wystąpieniami: prof. Jarosław Ławski, prof. Lilia Citko, dr Łukasz Zabielski i dr hab. Krzysztof Korotkich. Sesję zainaugurowano przy współudziale licznej grupy pracowników oraz kierownika Działu Naukowego Książnicy Podlaskiej, dra Łukasza Zabielskiego, którzy to skomplikowane technicznie przedsięwzięcie

8 Zob. na przykład: W. Szturc, Oko ikony, [w:] Bizancjum. Prawosławie. Romantyzm. Tradycja wschodnia w kulturze XIX wieku, red. J. Ławski, K. Korotkich, Seria „Antyk Romantyków”, Białystok 2004, s. 229-235. 


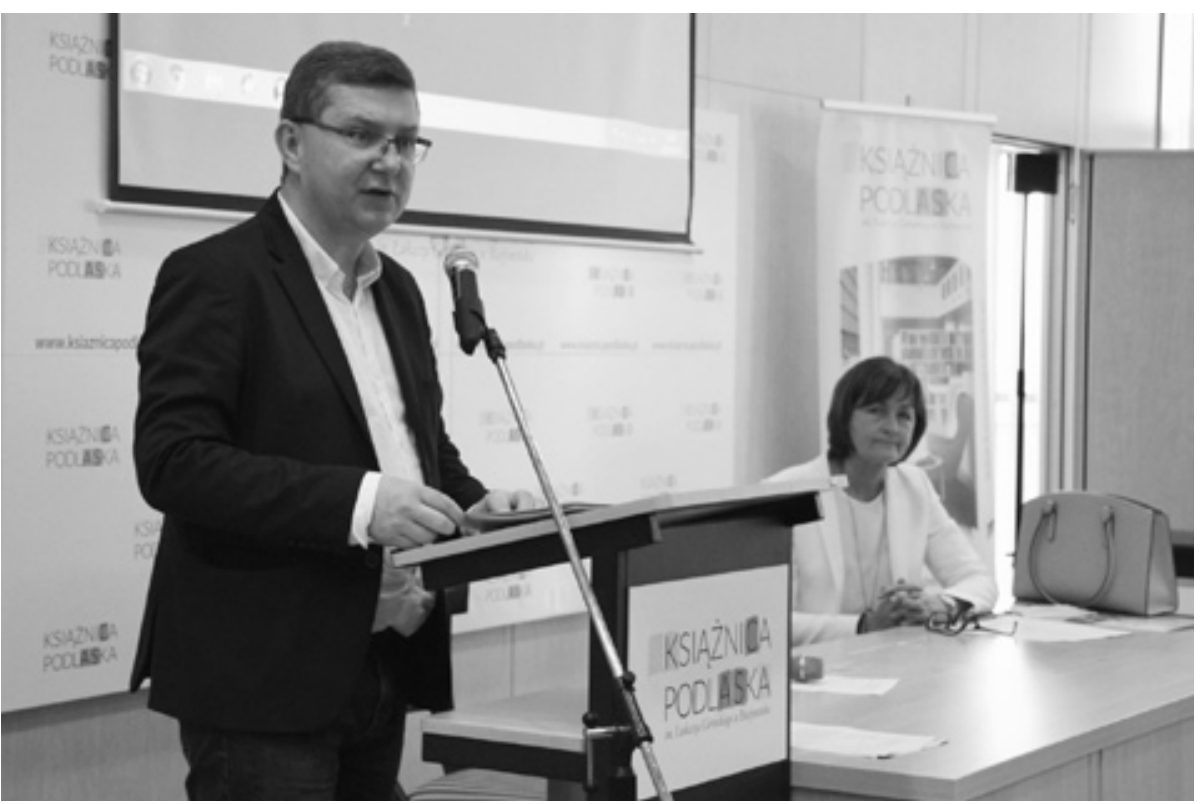

Na zdjęciu od lewej prof. Jarosław Ławski i prof. Lilia Citko

z powodzeniem koordynowali (łączono się m.in. z Kijowem, Wiedniem, Witebskiem, Warszawą, ale tylko raz wystąpiły kłopoty techniczne) ${ }^{9}$.

Obrady podzielono na dwie części - stacjonarną oraz online. W części pierwszej, stacjonarnej, wystąpili:

- prof. dr hab. Włodzimierz Szturc (Uniwersytet Jagielloński, Kraków), Teologia Wschodu i Zachodu w twórczości Jerzego Nowosielskiego;

- mgr Patryk Suchodolski (Książnica Podlaska im. Łukasza Górnickiego), Tykocińscy zakonnicy w pismach Zygmunta Glogera;

- dr Michał Piętniewicz (Uniwersytet w Białymstoku), Płonaca rosa róża. Aspekty filologiczne i teologiczne pism św. Jana od Krzyża;

- doc. dr Halina Turkiewicz (Uniwersytet Witolda Wielkiego w Kownie), Sfera sacrum we współczesnej polskiej literaturze Litwy (tekst nadesłany, odczytany).

9 Warto zaznaczyć, iż prowadzenie obrad w formule wideokonferencji stało się możliwe dzięki udostępnieniu przez Książnicę Podlaską nowoczesnego sprzętu specjalnie do tego celu zakupionego (co niejako sprowokowały pandemia i potrzeby podlaskich instytucji kulturalno-naukowych). 
Obrady poprowadzili w części wstępnej: prof. Jarosław Ławski (UwB) i prof. Lilia Citko (oboje UwB). W części drugiej (online) prowadzenie obrad przejęli: dr Krzysztof Rutkowski, dr hab. Krzysztof Korotkich oraz dr Łukasz Zabielski. Usłyszeliśmy między innymi następujące wystąpienia:

- dr hab. Marcello Ruta (Uniwersytet w Bernie, Szwajcaria), Ontological and hermeneutical considerations on Pavel Florenskij's essay The Church Ritual as a Synthesis of the Art;

- prof. Walentyna Bilacka (Narodowy Uniwersytet Techniczny „Dnipro Politechnika”, Ukraina), Молитва як фрагмент жанру в сучасному украӥнському ліро-епосі;

- mgr Anna Lebet-Minakowska (Muzeum Narodowe w Krakowie), Symbolika biblijna w sztuce Kościoła unickiego na przykładzie haftów liturgicznych w kolekcji rzemiosta artystycznego Muzeum Ksiażą Czartoryskich w Krakowie;

- dr Matteo Piccin (Uniwersytet Warszawski), Ziemia chłopom: biskup Eulogiusz między narodnictwem a nacjonalizmem;

- dr Jolanta Doschek (Uniwersytet Wiedeński, Austria), Krótka historia o opętaniu. O Matce Joannie od aniołów Jarostawa Iwaszkiewicza;

- prof. Светлана Ковпик (Państwowy Uniwersytet Pedagogiczny w Krzywym Rogu, Ukraina), Художественная интерпретация образа монаха в паломническом произведении В. Григоровича-Барского Странствования по святых местах Востока с 1723 по 1747 г2.;

- dr hab. Jarosław Karzarnowicz, prof. UwB, Żywoty św. Zosimy i Sabacjusza (Sawwatija) Sołowieckich w rękopisach biblioteki Monasteru Sołowieckiego z XVII wieku;

- doc. dr Artur Malinowski (Odeski narodowy Uniwersytet im. Ilji Miecznikowa, Ukraina), Філософія серия як трансфер християнської моралі в повістях Григорія Квітки-Основ'яненка;

- prof. Anna Mezenko (Odeski Uniwersytet Narodowy, Ukraina); Церковные названия внутрипоселенческих объектов в топонимной системе Беларуси: территориальная дифференциация (Witebski Uniwersytet Państwowy im. P.M. Maszeraua, Białoruś)

Sesja miała w pełni międzynarodowy charakter. Wzięło w niej udział 25 badaczy (w tym 13 zagranicznych) z Polski, Białorusi, Ukrainy, Szwajcarii, Niemiec, Litwy. Organizacja Konferencji była możliwa dzięki środkom 
MNiSW z programu pod nazwą „Regionalna Inicjatywa Doskonałości” realizowanego w latach 2019-2023 na Wydziale Filologicznym Uniwersytetu w Białymstoku w dyscyplinach językoznawstwo i literaturoznawstwo.

Była to nasza pierwsza - i udana - próba $^{10}$ dostosowania życia naukowego do warunków, ograniczeń, jakie narzuca pandemia. Zasadniczą kwestią okazało się przezwyciężenie trudności technicznych, co umożliwiło udostępnienie nowo zakupionego sprzętu przez Książnicę Podlaską oraz zachowanie zasad bezpieczeństwa i higieny, co niestety musiało skutkować ograniczeniem bezpośrednich spotkań i obradami częściowo w formie zdalnej. Zasadniczy zespół organizatorów i referentów spotkał się jednak 28 września, by podtrzymać tradycję bezpośrednich obrad, które jeszcze do lutego 2020 roku uważaliśmy za coś naturalnego, raz na zawsze danego. Jak się okazało: niesłusznie.

Chcielibyśmy w sposób szczególny podziękować Pani prof. Zofii Abramowicz za możliwość kontynuacji cyklicznych spotkań, za przekazanie ich w ręce kontynuatorów i następców. Dziękujemy tym referentom, którzy, jak prof. Włodzimierz Szturc oraz dr Michał Piętniewicz (obaj z Krakowa), osobiście stawili się na obradach. Słowa specjalnych podziękowań kierujemy do Pani mgr Ewy Frymus-Dąbrowskiej, która wielokrotnie modyfikowała piękny edytorsko Program sesji ${ }^{11}$, aktualizując go, a właściwie stale poszerzając. Można wyrazić uzasadnioną dumę z faktu, iż tak wielu badaczy z sześciu krajów sięgnęło po pióro, by swymi pracami, na przekór pandemii, zaświadczyć ciągłość tradycji naukowej nawet w nadzwyczajnych warunkach. Ich wysiłki przekaże potomnym monografia zapowiedziana na rok 2021.

Trzeba też jednak wyrazić nadzieję, iż VII Konferencja z tego cyklu odbędzie się już w formule li tylko stacjonarnej, że znów razem spotkamy się w Supraślu lub w Białowieży, na pewno zaś w Białymstoku.

10 Ale, dopowiedzmy, nie pierwsza na Uniwersytecie w Białymstoku, który od wiosny 2020 roku przeprowadził już kilka sesji w formule online.

11 VI Międzynarodowa Konferencja Naukowa z cyklu „,Chrześcijańskie dziedzictwo duchowe narodów słowiańskich. Język. Literatura. Kultura. Historia”: Monastycyzm i mistycyzm w literaturze, kulturze i języku Stowian”, Białystok - Supraśl, 28-29 września 2020. Program, red. K. Rutkowski, D. Kukiełko, opr. JMŁ, E. Frymus-Dąbrowska, Białystok: Wydawnictwo PRYMAT, Mariusz Śliwowski, 2020, ss. 16. 